\title{
Community Perceptions of Disaster Recovery Program after the February 2019 Earthquake in Sangir Balai Janggo District, Solok Selatan Regency, West Sumatera-Indonesia
}

\author{
* Tila Novita ${ }^{1}$ and Iswandi $\mathrm{U}^{2}$ \\ ${ }^{1}$ The Graduate Students of Geography Education, Universitas Negeri Padang, Indonesia \\ ${ }^{2}$ Master Program of Geography Education, Universitas Negeri Padang, Indonesia \\ Email : tilanovita92@gmail.com iswandi_u@yahoo.com
}

*Corresponding Author, Received: Februari 10, 2019, Revised: April 10, 2019, Accepted: May 10, 2019

\begin{abstract}
This research was aimed to analize community perception of disaster recovery after the February 2019 earthquake in Solok Selatan. It used a qualitative method and interactive analysis. The research location was Sangir Balai Jonggo in Solok Selatan Regency. Observation, interview, document study and FGD were conducted to collect desired data. Two types of data were obtained. Primary data were collected from the informants selected through purposive sampling including the local community and the government in the affected area, while secondary data were obtained from related local literatures. The informants were Sekcam (District Head) and the community affected by the disaster in Sangir Balai Janggo, Solok Selatan. Physical recovery was done in the 3 most damaged nagari (village). One of them is Nagari Sungai Kunyit. There were 67 severely damaged houses, 91 were moderately damaged, and 192 were slightly damaged. Futhermore, the earthquake also affected the facilities in 4 nagari in Sangir Balai Jonggo; 6 medical centres, 28 schools, and 18 mosques. The result showed that most community were satisfied with the recovery program and they gave positive feedback especially on the aid given to them. The recovery included donation for the victims like basic foods, clean water, instant foods, baby supplies, etc, therapy treatment by doctors and volunteers to help with their mental state and to build their confidence after the earthquake.
\end{abstract}

Keywords: Perception, Disaster, Recovery

\section{Introduction}

Society's paradigm of disaster recovery has not changed much. Many of them still assume that disaster is divine providence (Hermon, 2015; Hermon, 2017; Oktorie, 2017). It indicates a strong conventional paradigm in a society. Generally, they believe that disaster is God's punishment for sinners so they must accept it as a fruit of their sin, restraining them from making efforts to recover and prevent disaster (Bakornas PB, 2007; Hermon, 2010; Hermon, 2012; Hermon, 2016). Disaster prevention program in Indonesia tend to be ineffective. The prevention usually accentuates emergency phase, less integrated partial sectoral works, government-centered program and is limited to providing physical assistance. However, since the Yokohama Agreement, it starts to change the paradigm. It count heavily on community participation in reducing disaster risks with the spirit of Hyogo framework for action (HFA), formed at the conference of disaster risk reduction in Kobe, Japan 2005 with a theme: "Building the resilience of nation and communities to disasters".

According to Law No.24 2007 disasters are events or sequences that threaten and disrupt the lives and livelihoods of people caused by natural factors and/or non-natural factors and human factors resulting in human casualties, environmental damage, property losses, and psychological effects. Disasters can basically 
be in the form of war, drought, starvation, storm, flood, tsunami, landslides, erosion, earthquakes, nuclear explosions, epidemics, physical damage, loss of property, disability, accidents, transportation, mental damage and damage on the structure and social system (Abdullah, 2006; Hermon, 2009; Hermon, 2011; Hermon, 2014; Hermon, 2015). As a result, these natural disasters cause damage and disturb people's lives and livelihoods, including their psychological state, which can then cause affected individual or group to suffer from Post-Traumatic Stress Disorder (PTSD). Around 1.50\% populasi experienced Post-Traumatic Stress Disorder (PTSD) for four years because of disasters (Kinchin, 2007; Hermon, 2016; Oktorie, 2018). A study in America showed $15-43 \%$ women and 14-43\% experienced the trauma during their lives. In managing disaster are there four phases that should be done continuously. The phases are mitigation, emergency preparedness, recovery and reconstruction. The last two phases (recovery and reconstruction) have more opportunities to significantly reduce disaster risks and improve adaptation to disasters (Usamah and Haynes, 2011; Hermon et al., 2017; Hermon et al., 2018; Kristian and Oktorie, 2018; Hermon, 2019; Hermon et al., 2019). One of the effort in reconstruction phase is rebuilding the victim's house on the same spot or another spot in order to avoid disaster risks.

Solok Selatan is one of regencies in West Sumatera which is affected by the Earthquake on February 28 and its 3 districts (Sangir Balal Janggo, Sangir Batang Hari, Sangir Jujuan) were severely damaged. According to in BMKG (Meteorology Climatology Geophysics Council), Solok Selatan is an activity area of Sumatera Fault Zone where exactly are located Suliti and Siulak segments. Thus, prior to the implementation of community based disaster prevention in Solok Selatan, its community perceptions of disaster need to be studied. The term of disaster in this study limits to Earthquake disaster because Solok Selatan has never experienced the earthquake that has a big impact on its community conditions. The earthquake experience and the geological conditions of their home could be a lesson that change Solok Selatan community perceptions of alertness to the disaster and its recovery. This perceptions will be inherited from generation to generation and continuously remembered so they will be more prepared for the disaster. This study was aimed to describe Solok Selatan community perceptions of disaster recovery after the earthquake.

\section{Method}

This study was a descriptive qualitative study, a research that describes and analyses a condition in detail without any treatments on studied objects (Harliani 2014). This research described about community perceptions of disaster recovery after the earthquake in Sangir Balai Janggo Solok Selatan. Two types of data were collected. Primary data were collected through observation, interview, documentary study and FGD in order to find the community perceptions. Secondary data were obtained from related literatures like books, scientific journals, print or electric media, papers etc that could support the writer's analysis and understanding of the primary data (Triningsih, 2013). Observation was conducted to observe behavior of the object, in this case Sangir Balai Janggo community, and check informant's answer with reality. In this study, the writer observed the physical and environmental condition of the settlements in Sangir Balai Janggo. An interview was conducted with the local government to collect information about community understanding of disaster recovery program in the district after the earthquake. The interview was done on March 162019. Moreover, it also aimed to know what efforts were made and how the program was implemented in order to recover the community after the earthquake. The official included in the interview were the district secretary. The information of community perception was directly obtained from the people who lived in Sangir Balai Jangho and were affected by the earthquake. The method to analyze the data was interactive data analysis and the informants were selected through purposive sampling.

\section{Result and Discussion}

\section{Community Perception of Earthquake}

Perception is a process where someone chooses, organizes, interprets, translates and responds to information that comes from the surrounding environment (Schermerhon, 2010). Every individual will give different perceptions of the same situation because there are many factors that influence a person's perception. A disaster always gets a different response in society. From individuals in affected communities 
(Quarantelli, 1998; Oktorie, 2018) in the analysis, individual and institutional responses appear especially in those affected by disasters, are usually of resignation.

Mental resignation was due tue their thoughts disturbed by what happened to them. Whereas institutionally, response that can be given is making efforts to minimize the consequences of disaster. Sangir Balai Janggo is one of the districts in Solok Selatan Regency that experienced an earthquake with a major impact on people's lives. Based on the results of the interview with the local people the earthquake was the first earthquake in the Janggo Hall. Therefore for the recovery or countermeasures carried out by the community, two stages were implemented since previously there has never been an earthquake disaster in the area where the recovery program was carried out by BNPB (National Board for Disaster Management). Below are community perceptions of disaster recovery program:

\section{Community Perception of Physical Recovery}

The result in the field showed that the community strongly agreed with the recovery program by government (Hermon, 2009). According to them the physical recovery consisted of reconstructing damaged houses or facilities. The assistance provided varied depending on how severe the damage is. The earthquake inhibited their daily activities like working and going to school etc. Children could not go to school and parent could not work, leading to decreased family income. In addition to that the emergence of various diseases attacked children and adults because they were staying in tarpaulin floored refugee camps. Their perception of the disaster Physical recovery was that Sangir Balai Janggo has not been recovered fully yet. Most of people are still staying in the refugee area and educational activities has not function normally.

The data from the field showed that the numbers of damaged houses and facilities in 4 sub-districts in Sangai Balai Janggo District were: 1) Nagari Sungai Kunyit with 67 severely damaged houses , 91 moderately damaged houses, and 192 slightly damaged houses, 2) Nagari Sungai Kunyit Barat with 16 severely damaged, 24 moderately damaged and 102 slightly damaged, 3) Nagari Talunan Maju with 21 severely damaged, 33 moderately damaged and 62 slightly damaged, 4) While Nagari Talao was not really affected by the earthquake, proven by no damaged buildings found in the field (Secondary data from the district office of Sangir Balai Janggo). The other damaged buildings were places of worship like Musholla/mosque and health facilities. For example, 7 mosques in Nagari Sungai Kunyit, 3 in Nagari Sungai Kunyit Barat, 5 in Talunan Maju, and 3 in Nagari Talao (BPBD Solok Selatan). The data of damaged health facilities showed that 3 units were severely damaged in Nagari Sungai kunyit, 1 unit were in Nagari Sungai Kunyit Barat, and 1 unit in Nagari Talunan Maju (Secondary data from the district office). However, the earthquake did not damage roads and bridges but it damaged buildings (BPBD Solok Selatan).

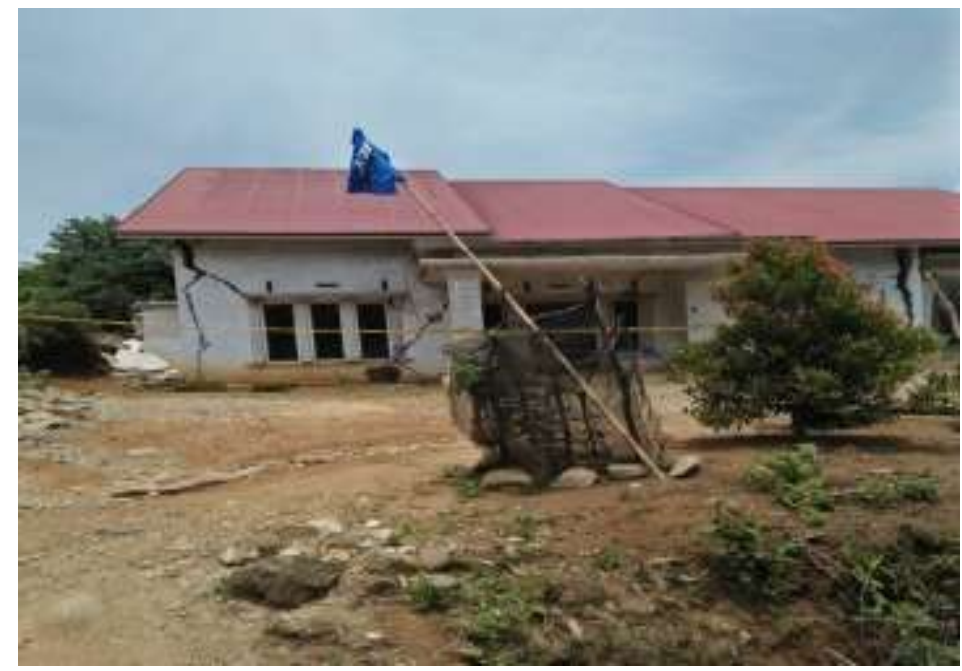

Figure 1. A House Damaged by the Earthquake Source: Documentation in 2019 


\section{Community Perception of Social Recovery}

The community perception of social condition recovery in sangir balai janggo were studied based on 3 variables: 1) Community perception of psychological recovery, 2) Community perception of economic recovery and 3) Community perception of educational recovery.

\section{Community Perception of Psychological Recovery}

The community perception of psychological recovery performed by psychologists and volunteers was very positive. They said that this recovery was very helpful for the victims. The treatment given was named Trauma Healing therapy conducted by psychologists from HB Saanin Mental Asylum. "The community were very happy for psychologists visiting their camps and giving therapy to adults and children", said the chief of local health agency of Solok Selatan, Novirman. The psychologists, medical specialist and volunteers helped them reducing their sadness and building their confidence.

The main purpose of trauma healing is to build victim's confidence so that their trauma can be eliminated through strengthened self defense mechanism. This healing therapy was given to adults and children so their fear of earthquake could be reduced or eliminated. On Friday (1/3), the local government assigns child and surgical specialists to give therapy to the earthquake victims in order to erase their trauma and rebuild their confidence. On Wednesday (6/3) the medical specialists were again visiting the victims to carry out further therapy. The chief executive of BPBD Solok Selatan, Jhonny Hasan Basri, when this research was conducted, told that the victims were still staying in refugee area. In addition, the Governor of West Sumatera said that the earthquake victims are the victims of psychological trauma because they are afraid to go home after the disaster.

Table 1. The Data of the Victims Treated with Trauma Healing Therapy in Sangir Solok Regency

\begin{tabular}{|c|c|c|c|c|c|c|c|c|c|}
\hline No & Name of District & $\begin{array}{l}\text { Health } \\
\text { Center }\end{array}$ & $\begin{array}{l}\text { Name of Nagari } \\
\text { (Sub-district) }\end{array}$ & Toddler & Juvenile & Teenager & Adult & Senior & Total \\
\hline \multirow[t]{2}{*}{1} & $\begin{array}{l}\text { Sangir Balai } \\
\text { Janggo }\end{array}$ & Talunan & $\begin{array}{l}\text { Sungai Kunyit } \\
\text { Barat }\end{array}$ & 422 & 795 & 625 & 1371 & 612 & 3826 \\
\hline & & & Talunan Maju & 407 & 767 & 603 & 1322 & 590 & 3689 \\
\hline
\end{tabular}

\section{Community Perception of Economic Recovery}

In term of economic recovery, the community said that there was no significant economic recovery given yet. The economic assistance was from the local government, outside the district, and volunteers in form of basic food for their daily needs in the camps. This had caused public concern about economic activities. This could be seen from their obstructed daily activities. The trauma made them unable to go to work and afraid of leaving their family. So, the earthquake affected their financial sources because the earthquake destroyed their working place for example a damaged unit of office in Nagari Sungai Kunyit.

\section{Community Perception of Educational Recovery}

The community perception of this recovery was that the educational activities had already begun but had not been fully recovered to its normal activities because some of them victims were still staying in the camps and afraid of going home due to the aftershocks (the district secretary of Sangir Balai Janggo). As for the victims with slightly damaged house, they started to go back to their houses and do their routines and their children started to go to school. Moreover, the location of schools was far from the local settlement, keeping the educational activities from going back to normal. From the field the data of damaged education facility were found. There were 8 units in Nagari Sungai Kunyit, 6 units in Nagari Sungai Kunyit Barat, 11 units in Nagari Talunan Maju and 3 units in Nagari Talao.

\section{Conclusion}

An earthquake could negatively affects one's life. Someone could lost their family, houses and other pproperties. Damages caused by earthquakes need immediate recovery. So is the earthquake damage in Sangir Balai Janggo in Solok Selatan. The earthquake on February 28 had destroyed houses, buildings and 
facilities. This recovery was carried out depending on the damage level found in the field. It was aimed to bring the community activities back to normal as it was before. The most important recovery was psychology recovery of the community so that their trauma and fear could be erased and they can do their normal daily activities. Generally, the community of Sangir Balai Janggo were very positive towards each recovery carried out by the government and volunteers. However, very few of them stated that economic recovery and educational recovery was not really significant. They said that the economic assistance given to them was from donors and volunteers.

\section{References}

Bakornas Penanggulangan Bencana. 2007. Pengenalan Karakteristik Bencana dan Upaya Mitigasinya di Indonesia. Edisi II.

Fatmah. 2009. Model Mitigassi Kebakaran Berbasis Masyarakat. Jurnal Kesmas Nasional, Vol 4 No. 3 , Desember 2009 .

Fanni, H. 2014. Persepsi Masyarakat Kampung Cieteung, Kabupaten Bandung tentang Rencana Relokasi akibat Bencana Banjir. Vol. 25.No.1. Jurnal Perencanaan Wilayah dan Kota

Hermon, D. 2009. Dinamika Permukiman dan Arahan Kebijakan Pengembangan Permukiman pada Kawasan Rawan Longsor di Kota Padang. Disertasi. IPB Bogor.

Hermon, D. 2010. Geografi Lingkungan: Perubahan Lingkungan Global. UNP Press.

Hermon, D. 2011. Studi Karakteristik Epipedon berdasarkan Penggunaan Lahan di Kecamatan X Koto Kabupaten Tanah Datar. Universitas Andalas.

Hermon, D. 2012. Mitigasi Bencana Hidrometeorlogi: Banjir, Longsor, Degradasi Lahan, Ekologi, Kekeringan, dan Puting Beliung. UNP Press. Padang.

Hermon, D. 2014. Impacts of Land Cover Change on Climate Trend in Padang Indonesia. Indonesian Journal of Geography. Volume 46. Issue 2. p: 138-142. Fakultas Geografi Universitas Gajah Mada.

Hermon, D. 2015. Geografi Bencana Alam. Jakarta: PT RajaGrafindo Persada.

Hermon, D. 2016. Mitigasi Perubahan Iklim. Rajawali Pers (Radjagrafindo).

Hermon, D. 2016. The Strategic Model of Tsunami Based in Coastal Ecotourism Development at Mandeh Regions, West Sumatera, Indonesia.Journal of Environment and Earth Science. Volume 6.

Hermon, D. 2017. Climate Change Mitigation. Rajawali Pers (Radjagrafindo).

Hermon, D., P. Iskarni., O. Oktorie and R. Wilis. 2017. The Model of Land Cover Change into Settlement Area and Tin Mining and its Affecting Factors in Belitung Island, Indonesia. Journal of Environment and Earth Science. Volume 7 No. 6. p: 32-39. IISTE.

Hermon, D., A. Putra and O. Oktorie. 2018. Suitability Evaluation of Space Utilization Based on Enviromental Sustainability at The Coastal Area of Bungus Bay in Padang City, Indonesia. International Journal of GEOMATE. Volume 14. Issue 41. p: 193-202. Geomate International Society.

Hermon, D. 2019. Evaluation of Physical Development of The Coastal Tourism Regions on Tsunami Potentially Zones in Pariaman City-Indonesia. International Journal of GEOMATE. Volume 17. Issue 59. p: 189-196. Geomate International Society.

Hermon, D., Ganefri, Erianjoni, I. Dewata, P. Iskarni and Alexander Syam. 2019. A Policy Model of Adaptation Mitigation and Social Risks The Volcano Eruption Disaster of Sinabung in Karo Regency-Indonesia. International Journal of GEOMATE. Volume 17. Issue 60. p: 190-196. Geomate International Society.

Kristian, A and O. Oktorie. 2018. Study of Coastal Mangrove Conservation in the World. Sumatra Journal of Disaster, Geography and Geography Education. Volume 2. Issue 1. p: 49-52

Majalah Interaksi, No.2/ tahun IX/2007.ISSN 0216-017X Bencana Bukan Keniscayaan. Pusat Promosi Kesehatan - Depkes RI. 
Majalah Interaksi, No.2/ tahun IX/2007.ISSN 0216-017X Kesedihan Ganda Korban Bencana, Ancaman Gangguan Mental Serius. Pusat Promosi Kesehatan - Depkes RI.

Oktorie, O. 2017. A Study of Landslide Areas Mitigation and Adaptation in Palupuah Subdistrict, Agam Regency, West Sumatra Province, Indonesia. Sumatra Journal of Disaster, Geography and Geography Education. Volume 1. Issue. 1. p: 43-49. Master Program of Geography Education.

Oktorie, O. 2018. Model Kebijakan Responsif Pemulihan Bencana Letusan Gunung Sinabung. Jurnal Kapita Selekta Geografi. Volume 1. Issue 1. p: 15-20

Pan America Health Organization (PAHO). 2006. Bencana Alam Perlindungan Kesehatan Masyarakat, Penerbit buku EGC.

Purwana, R. 2013. Manajemen Kedaruratan Kesehatan Lingkungan dalam Kejadian Bencana. Jakarta. Rajagrafindo Persada

Yayasan IDEP. 2007. Panduan Penanggulangan Bencana Berbasis Masyarakat. Jakarta

Yayasan Jambo Minda. 2010. Panduan Pendidikan Penanggulangan Bencana untuk Sekolah. Jakarta 